International Journal of Instruction e-ISSN: 1308-1470 • www.e-iji.net

Article submission code: 20191024015314

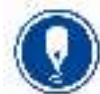

January $2021 \bullet$ Vol.14, No.1

p-ISSN: 1694-609X

pp. 691-708

Received: $24 / 10 / 2019$

Revision: 22/07/2020
Accepted: 14/08/2020

OnlineFirst:10/11/2020

\title{
Green Chemistry Practicums at Chemical Equilibrium Shift to Enhance Students' Learning Outcomes
}

\section{Wayan Redhana}

Universitas Pendidikan Ganesha, Bali, Indonesia, redhana.undiksha@gmail.com

\section{Nyoman Suardana}

Universitas Pendidikan Ganesha, Bali, Indonesia, suardana_sgr@yahoo.com

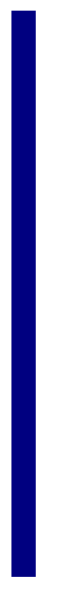

Evidences showed that students' chemistry learning outcomes were still low. One of the causes was the chemistry practicums carried out so far were traditional chemistry practicums. Therefore, it needed to be reoriented towards the practicum. Thus, this study aimed to investigate the effect of green chemistry practicums on students' learning outcomes on the topic of chemical equilibrium shifts. This study used two classes, namely one class as a control group and another class as an experimental group. Each class consisted of 40 students, respectively. The traditional chemistry practicums were taught to the control group, while the green chemistry practicums were taught to the experimental group. Analysis of covariance was used to test a hypothesis at a significance level of $5 \%$. The results of the study showed that there was a significant difference in the learning outcomes of students. The methods of green chemistry practicums were better in improving the learning outcomes than those of traditional chemistry practicums. It was recommended that senior high school teachers can apply these methods to improve students' learning outcomes.

Keywords: analysis of covariance, green chemistry practicums, chemical equilibrium shift, traditional chemistry practicums, learning outcomes

\section{INTRODUCTION}

Chemistry is a part of the sciences. Therefore, it has the same characteristics as the sciences. These characteristics are the objects of chemistry, how to obtain, and their usefulness. It is the science that seeks answers to the questions of what, why, and how natural phenomena relating to matters in terms of the properties, composition, and structure of the substances, the changes experienced by the substances, and the energy released or absorbed during this change processes (Rocke \& Usselman, 2020).

Chemistry cannot be separated from experimental or practicum activities. Most of the chemistry teachers, in particular, consider that chemistry practicums are less important to develop the students' understanding. Teachers focus more on explaining chemistry than practicing chemistry. This is caused by several things. First, the chemistry

Citation: Redhana, I W. \& Suardana, I N. (2021). Green Chemistry Practicums at Chemical Equilibrium Shift to Enhance Students' Learning Outcomes. International Journal of Instruction, 14(1), 691-708. https://doi.org/10.29333/iji.2021.14142a 
practicums spend a lot of time so that the teachers can not complete all the content of the chemistry subject matters. Second, the chemistry practicums spend a lot of money because the price of chemicals is very expensive. Third, the chemistry practicums also require special equipment, such as Erlenmeyer and measuring cups. Fourth, the materials used in the chemistry practicums are quite dangerous. Fifth, the chemistry practicums require special preparation and handling of materials, for example when students take the concentrated nitric acid solution, this should be done in a fume cabinet. As a result of the lack of chemistry practicums, the knowledge constructed by students during the chemistry learning process is less depth. Concerning the inadequate understanding of students toward chemistry concepts, Redhana et al. (2017) reported that the teaching and learning conducted by the chemistry teachers have not been able to change the students' conceptions so that students experience misconceptions on the topic of buffer solutions. Teachers also pay less attention to students' learning styles (Sudria et al., 2018). The students' learning styles should be used as materials for designing learning plans so that the students understand the chemistry concepts more easily. Besides, local cultures in the students' environment are a rich context for enhancing students' critical thinking skills (Suardana et al., 2018).

The practicums taught at schools in Indonesia and around the world are based on traditional chemistry practicums. The traditional practicums are practicums that are usually carried out in accordance with procedures commonly found in textbooks (Taha et al., 2019). In the traditional practicums on the chemical equilibrium shift, the chemicals used are generally synthetic chemicals produced by industry, such as $\mathrm{Cu}$ metal, $\mathrm{HNO}_{3}, \mathrm{KSCN}$, and $\mathrm{FeCl}_{3}$. Most compounds used in the traditional chemistry practicums are dangerous to the health of students and can pollute the environment (Listyarini, 2019).

On the other hand, the green chemistry practicums use materials that are safe for humans and friendly to the environment. For example, in the green chemistry practicum to study the chemical equilibrium shift, specifically, the effect of concentration and temperature on chemical equilibrium shifts, the materials used are black tea, vinegar, soapy water, starch colloids, and iodine tinctures (Beyond Benign, 2014). All these materials can be degraded by microorganisms in the environment.

Practicums plays an important role in improving students' learning outcomes. Through practicums, students can verify the principles, theories, or laws learned in the subject matters. Thus, students' understanding of the principles, theories, or laws learned in subject matters, especially chemistry, will be deeper (Ryan et al., 1996; Makarem et al., 2001; Ural, 2016; Tesfamariam et al., 2017). In other words, students will be able to remember the subject matters longer. Bruno \& Dell'Avana (2018) reported that reflective practicum affected students' reflective practice. This reflective practice increased students' learning responsibilities which could further improve students' learning outcomes. Meanwhile, Hikmah et al. (2018) stated that science process skills were a scientific method for achieving good knowledge. Putra et al. (2018) revealed that practicum methods were able to develop basic science skills. 
In this study, the effect of two practicum methods, namely the green chemistry practicums and the traditional chemistry practicums, were studied on students' learning outcomes. In both practicum methods, the effect of concentration and temperature on the chemical equilibrium shift was investigated in this study. These two practicum methods had different characteristics. The first method used materials that were safe for humans and friendly to the environment, for example, black tea, vinegar, soapy water, starch colloids, and iodine tinctures. On the other hand, the second method used synthetic materials that were generally dangerous for humans and difficult to be degraded by microorganisms in the environment, for example $\mathrm{Cu}$ metal, $\mathrm{HNO}_{3}, \mathrm{FeCl}_{3}$, and $\mathrm{KSCN}$. On the other hand, the effect of pressure and catalyst on equilibrium shifts was not investigated in this study.

\section{METHOD}

\section{Design of the Study}

To test the effectiveness of the green chemistry and the traditional chemistry practicum methods in improving students' learning outcomes, the research type used was a quasiexperiment because it involved intact classes. The research design used in the study was non-equivalent pretest and posttest control groups.

\section{Variables of the Study}

The study involved three variables, i.e. an independent variable, a dependent variable, and a covariate variable. The independent variable was a manipulation variable in the form of the chemistry practicum methods consisting of two levels, i.e. the traditional and the green chemistry practicum methods. The dependent variable was the students' learning outcomes in which their scores depended on the independent variable. The covariate variable was based on students' prior knowledge and was used to equalize the subject variations in the study.

\section{Population and Samples}

A total of 235 eleventh-grade students across six classes of the natural class of State High School 4 Singaraja Bali Indonesia were used as the population of this study. To meet the needs of the research design, two classes or groups in the form of intact classes were selected by a random cluster technique. One class was used as a control group, and another was used as an experimental group; each class consisted of 40 students.

\section{Procedures for Data Collection}

The experimental group was taught by applying the methods of the green chemistry practicums, whereas the control group was taught by applying the method of the traditional chemistry practicums. Both of these methods used different practicum materials. Meanwhile, the same learning models, namely the discovery learning models, were applied to both groups. The syntax of the discovery learning model is (1) stimulation, (2) problem statement, (3) data collection, (4) data processing, (5) verification, and generalization. Both groups were taught on the same topics, namely the 
effect of concentration and temperature on the chemical equilibrium shift. Likewise, both groups were taught by the same teacher.

Lesson plans and students' worksheets were the learning tools used in this study. The students' worksheets of the traditional chemistry practicums were derived from chemistry practicum procedures, generally found in chemistry textbooks. The procedures of the traditional chemistry practicum of the effect of temperature and concentration on the equilibrium shift were as follows.

The effect of temperature on the chemical equilibrium shift was as follows. (1) Prepare 2 test tubes, each was filled with $5 \mathrm{~mL}$ of concentrated $\mathrm{HNO}_{3}$ solution. (2) Take $1 \mathrm{~cm}$ of $\mathrm{Cu}$ metal, then put it in a test tube containing concentrated $\mathrm{HNO}_{3}$ solution, then close the test tube tightly. (3) Observe the reaction that occurred. (4) Put one of the test tubes into hot water, observe the colour change of the gas in the test tube. (5) Compare with the other test tube (the control). (6) Insert the same test tube into the ice bath, observe the colour change of the gas in the test tube. (7) Compare with the other test tube (the control). Meanwhile, the effect of concentration on the chemical equilibrium shift was as follows. (1) Put $2 \mathrm{~mL}$ of $\mathrm{FeCl}_{3}$ solution into test tube 1 and $2 \mathrm{~mL}$ of $\mathrm{KSCN}$ solution into test tube 2. (2) Observe the colour of both solutions. (3) Mix the two solutions in the test tube. (3) Observe the colour change that occurred. (4) Divide the solution into 2 test tubes of the same volume. (5) Add $1 \mathrm{~mL}$ of $\mathrm{FeCl}_{3}$ solution to the test tube 1. (6) Observe the colour change of the solution. (7) Add $1 \mathrm{~mL}$ of KSCN solution to test tube 2. (8) Observe the colour change of the solution.

Meanwhile, the students' worksheets of the green chemistry practicums were derived from procedures developed by Beyond Benign (2014). The procedures of the green chemistry practicums about the effect of the temperature on the chemical equilibrium shift were: (1) add a few drops of iodine tincture to some starch solution; note that the formation of a blue-black colour, (2) heat the solution to about $80^{\circ} \mathrm{C}$; note that the blueblack colour disappears, and (3) cool the container by placing it in ice. On the other hand, the procedures of the green chemistry practicums about the effect of concentration on the chemical equilibrium shift were: (1) place some black tea solution in three 125 $\mathrm{mL}$ Erlenmeyer flasks; one of these will be used as a control, (2) to the other flask, add a few drops of vinegar; note that the colour becomes brighter and compare to the control flask, and (3) to the remaining flask, add few drops of soapy water; note that the colour becomes darker and compare to the control flask.

At the end of the practicums, students in both groups were given an open questionnaire. The purposes of giving this questionnaire were to know students' opinions toward the practicums being followed.

\section{Instruments of the Study}

Students' prior knowledge and learning outcomes were tested in this study. The prior knowledge test and the learning outcome test used different tests. The prior knowledge test was an essay test consisting of 10 items, while the learning outcome test was an objective test consisting of 40 items. The validity, reliability, difficulty level, and 
different power index of the prior knowledge test and the learning outcome test were respectively shown in Table 1 .

Table 1

Validity, reliability, difficulty level, and different power index of the prior knowledge test and the learning outcomes test

\begin{tabular}{llllll}
\hline No & Types of tests & Validity & Reliability & $\begin{array}{l}\text { Difficulty } \\
\text { level }\end{array}$ & $\begin{array}{l}\text { Different } \\
\text { power index }\end{array}$ \\
\hline 1 & Prior knowledge test & $0.32-0.69$ & 0.73 & $0.32-0.68$ & $0.29-0.74$ \\
2 & Learning outcome test & $0.20-0.49$ & 0.78 & $0.37-0.76$ & $0.26-0.63$ \\
\hline
\end{tabular}

In addition to using instruments in the form of tests, this study also used instruments in the form of an open questionnaire. This questionnaire aimed to find out students' opinions on the chemistry practicum carried out. Some questions asked concerning the implementation of chemistry practicum in the control and the experimental group were as follows. (1) Do you feel safe in carrying out the chemistry practicum with these materials? Explain! (2) Are you motivated to carry out the chemistry practicum using those materials? Explain! (3) Does your understanding of the chemical equilibrium topic increase after carrying out the practicum using those materials? Explain!

\section{Data Analysis}

Data obtained in this study were scores of students' prior knowledge and scores of students' learning outcomes. These data were analyzed by descriptive and inferential statistics. Analysis of the descriptive statistics included means and standard deviations. The inferential statistics used was an analysis of covariance at the significance level of $5 \%$. All data analyses were conducted by the SPSS 21 computer program. Meanwhile, students' opinion data collected from open questionnaires were analyzed descriptively.

\section{FINDINGS}

\section{Statistics of the Study Results}

Data obtained in this study were scores of students' prior knowledge and students' learning outcomes. These data that were presented in Table 2 indicated that the score means of the students' prior knowledge were similar between the control and the experimental groups. While the score means of students' learning outcomes in the control group was different from the score means of the students' learning outcomes in the experimental group. Meanwhile, standard deviations of the students' prior knowledge between the control and experimental group were similar. The standard deviations of the students' learning outcomes between the control and experimental group were similar, as well. 
Table 2

Mean scores and standard deviations of the pretest and posttest in the control and experimental groups

\begin{tabular}{lllll}
\hline \multirow{2}{*}{ Statistics } & Pretest & & Posttest & \\
\cline { 2 - 5 } & Control & Experiment & Control & Experiment \\
\hline Mean & 48.45 & 49.87 & 69.8 & 79.9 \\
\hline Standard deviation & 16.71 & 16.31 & 5.67 & 5.53 \\
\hline
\end{tabular}

\section{Tests of Assumptions}

To be able to do a hypothesis test, the assumption tests needed to be done first. The assumption tests for covariance analysis included tests of normality, homogeneity of variances, linearity, and homogeneity of regression slopes (Pallant, 2001). The results of these assumption tests were shown in Tables 3, 4. 5, and 6 respectively.

Table 3

Test of normality

\begin{tabular}{lllll}
\hline \multirow{2}{*}{ Tests } & \multirow{2}{*}{ Groups } & \multicolumn{3}{l}{ Shapiro-Wilk } \\
\cline { 3 - 5 } & & Statistic & df & Sig. \\
\hline Posttest & Experiment & 0.945 & 40 & 0.050 \\
\cline { 2 - 5 } & Control & 0.948 & 40 & 0.064 \\
\hline \multirow{2}{*}{ Pretest } & Experiment & 0.957 & 40 & 0.134 \\
\cline { 2 - 5 } & Control & 0.952 & 40 & 0.088 \\
\hline
\end{tabular}

Table 4

Test of homogeneity of variance

\begin{tabular}{llllll}
\hline Tests & Statistic & Levene Statistic & df1 & df2 & Sig. \\
\hline Posttest & Based on Mean & 0.109 & 1 & 78 & 0.742 \\
\hline Pretest & Based on Mean & 0.279 & 1 & 78 & 0.599 \\
\hline
\end{tabular}

Table 5

Test of linearity in the experimental group

\begin{tabular}{|c|c|c|c|c|c|c|c|}
\hline Interaction & Groups & Description & $\begin{array}{l}\text { Sum of } \\
\text { Squares }\end{array}$ & df & $\begin{array}{l}\text { Mean } \\
\text { Square }\end{array}$ & $\mathrm{F}$ & Sig. \\
\hline \multirow{5}{*}{$\begin{array}{l}\text { Posttest* } \\
\text { Pretest }\end{array}$} & \multirow{3}{*}{$\begin{array}{l}\text { Between } \\
\text { Groups }\end{array}$} & (Combined) & 741.535 & 24 & 30.897 & 1.023 & 0.495 \\
\hline & & Linearity & 54.829 & 1 & 54.829 & 1.815 & 0.001 \\
\hline & & Deviation from Linearity & 686.707 & 23 & 29.857 & 0.988 & 0.523 \\
\hline & \multicolumn{2}{|c|}{ Within Groups } & 453.208 & 15 & 30.214 & & \\
\hline & \multicolumn{2}{|l|}{ Total } & 1194.744 & 39 & & & \\
\hline
\end{tabular}


Table 6

Test of linearity in the control group

\begin{tabular}{|c|c|c|c|c|c|c|c|}
\hline Interaction & Groups & Description & $\begin{array}{l}\text { Sum } \\
\text { Squares }\end{array}$ & of df & Mean Square & $\mathrm{F}$ & Sig. \\
\hline \multirow{5}{*}{$\begin{array}{l}\text { Posttest* } \\
\text { Pretest }\end{array}$} & \multirow{3}{*}{$\begin{array}{l}\text { Between } \\
\text { Groups }\end{array}$} & (Combined) & 711.702 & 27 & 26.359 & 0.581 & 0.883 \\
\hline & & $\begin{array}{l}\text { Linearity } \\
\end{array}$ & 13.251 & 1 & 13.251 & 0.292 & 0.034 \\
\hline & & $\begin{array}{l}\text { Deviation } \\
\text { Linearity }\end{array}$ & 698.451 & 26 & 26.864 & 0.592 & 0.873 \\
\hline & \multicolumn{2}{|c|}{ Within Groups } & 544.792 & 12 & 45.399 & & \\
\hline & \multicolumn{2}{|c|}{ Total } & 1256.494 & 39 & & & \\
\hline
\end{tabular}

Table 7

Test of homogeneity of regression slope

\begin{tabular}{llllll}
\hline Source & Type III Sum of Squares & df & Mean Square & F & Sig. \\
\hline Pretest & 61.492 & 1 & 61.492 & 1.961 & 0.165 \\
\hline Group*Pretest & 7.600 & 1 & 7.600 & 0.242 & 0.624 \\
\hline
\end{tabular}

The test of normality used Shapiro-Wilk's tests. Based on these tests, all significant values in the Shapiro-Wilk's test were more than 0.050 for both groups (Table 3 ). This confirmed that the data of students' prior knowledge and learning outcomes in both groups were normally distributed. The test of homogeneity of variances for all pretests and posttests resulted in a significant value of more than 0.050 (Table 4). This confirmed that the variances of the students' prior knowledge and the students' learning outcomes for both groups were homogeneous. The test of linearity produced a significant value of less than 0.050 (Table 5 and 6). This confirmed that the relationship between the scores of pretest and posttest in the control and experimental groups was linear. The test of homogeneity of regression slopes produced a significant value of more than 0.050 (Table 5 and 6). The results of the test confirmed that the regression slope of the line of the control group and the experimental group was homogeneous. Besides, a result of the pretest (covariate variable) was not significant $(p>0.050)$ (Table 7). This meant that there was not a significant difference between the scores of the pretest in the control and the experimental groups.

\section{Test of Hypothesis}

Because all tests of assumptions met the criteria, the test of analysis of covariance could be continued. The hypotheses tested were as follows:

$\mathrm{H}_{0}$ : there was a significant difference between the students' learning outcomes being taught by the method of green chemistry practicums and the students' learning outcomes being taught by the method of the traditional chemistry practicums.

$\mathrm{H}_{\mathrm{a}}$ : there was not a significant difference between the students' learning outcomes being taught by the methods of green chemistry practicums and the students' learning outcomes being taught by the method of the traditional chemistry practicums. 
The test of analysis of covariance was conducted at the significance level of 5\% and the results were presented in Table 7 . Based on the test of analysis of covariance, the following results were obtained. Firstly, there was not a significant difference between the pretest scores in the control group and the pretest scores in the experimental group $(\mathrm{p}>0.050)$. This showed that the difference that occurred in the posttest was not caused by the difference of pretest (covariate variable), but it was a result of the difference of manipulation/treatment (independent variable). Secondly, there was a significant difference between the students' learning outcomes being taught by the methods of green chemistry practicums and the traditional chemistry practicums $(p<0.050)$. Meanwhile, the data in Table 2 showed that the score mean of students' learning outcomes in the experimental group was higher than that of the students' learning outcomes in the control group. This suggested that the methods of green chemistry practicums were better than those of the traditional chemistry practicums in improving students' learning outcomes.

Table 8

Summary results of hypothesis testing

\begin{tabular}{llllll}
\hline Source & Type III Sum of Squares & df & Mean Square & F & Sig. \\
\hline Pretest & 60.480 & 1 & 60.480 & 1.948 & 0.167 \\
\hline Group (Posttest) & 2019.409 & 1 & 2019.409 & 65.040 & 0.000 \\
\hline
\end{tabular}

Data of students' opinions on the chemistry practicum that is followed can be briefly described as follows.

(1) Do you feel safe in carrying out the chemistry practicum with these materials? Explain!

Students in the experimental group said that they felt safe using materials used in the green chemistry practicums. They have also tried these practicums at home because the materials can be bought in general stores at low prices. On the other hand, students in the control group did not feel comfortable using chemicals used in the traditional chemistry practicums. Some students even feel a little itchy because of these chemicals.

(2) Are you motivated to carry out the chemistry practicum using those materials? Explain!

Students in the experimental group said that they were motivated to carry out practicums and also study chemistry. This was caused by the materials, procedures, and reactions occurred were not commonly found in textbooks. They tried to find this out them by searching journal articles. On the other hand, students in the control group said that the chemistry practicums were ordinary because the materials, procedures, and reactions occurred were already widely found in textbooks.

(3) Does your understanding of the chemical equilibrium topic increase after carrying out the practicum using those materials? Explain!

Students in the experimental group said that their understanding of the topic of chemical equilibrium increased because they were motivated to study chemistry through the green 
chemistry practicums. Besides, their curiosity also increased by finding information related to the principles of green chemistry, the dangers of chemicals, materials, procedures, and reactions through various sources, especially journal articles. On the other hand, students in the control group also felt that their understanding increased because they had done the practicums and could verify the principles learned on the topic of chemical equilibrium.

\section{DISCUSSION}

The results of this study showed that there was a significant difference between the students' learning outcomes taught by applying the methods of green chemistry practicums and the students' learning outcomes taught by applying the methods of the traditional chemistry practicums. Based on the mean scores of learning outcomes as illustrated in Table 2, it was evident that the students' learning outcomes taught by the method of green chemistry practicums were higher than the students' learning outcomes taught by the method of the traditional chemistry practicums. Therefore, it was concluded that the methods of green chemistry practicums are more effective than those of the traditional chemistry practicums in improving the students' learning outcomes. These were caused by several reasons. Firstly, students felt safer working with materials that were not harmful on the green chemistry practicums. In the green chemistry practicums for the chemical equilibrium shift, the materials used included black tea, vinegar, soapy water, starch colloids, and iodine tinctures. All of these materials were safe for humans and friendly for the environment. This was supported by the opinions of one of the students who stated:

"Materials used in the green chemistry practicums are materials that are often used and even consumed in daily life, such as black tea. I feel safe working with these materials in a chemical practicum. Also, these materials are environmentally friendly."

This safety was important so that students did not feel afraid to do practicums. Feelings of fear would affect interest and motivation to learn. With materials that were safe for humans and friendly for the environment, students became motivated to learn chemistry. This learning motivation will affect students' learning outcomes. In connection with this motivation, one of the students stated:

"With materials that were environmentally friendly, the green chemistry practicum encouraged us to repeat the practicums at home and motivated us to learn chemistry concepts to solve the problems encountered."

Another student said:

"Information relating to materials, procedures, and reactions that take place in the green chemistry practicums are not found in textbooks. I searched for this information by searching various sources on the internet, especially journal articles."

Secondly, the green chemistry practicums did not require special lab facilities, such as fume hoods, goggles, lab coats, or gloves. Thirdly, students could repeat the practicum several times without worrying about the cost spent. This was because the prices of materials used in the green chemistry practicums were cheap and these materials could 
be obtained easily by buying in stores, stalls, or pharmacies. Students could try these green chemistry practicums not only at school but also at home (Hjeresen et al., 2000). Fourthly, the green chemistry practicums did not require special types of equipment, but could utilize used goods or plastic wastes, such as plastic glasses or bottles. This was caused by the materials used in the green chemistry practicums were not corrosive.

In the green chemistry practicums, on the effect of temperature on the chemical equilibrium shift, the materials used were colloidal starch and iodine tincture. The reactions that occurred could be shown in Figure 1.

$$
\begin{array}{cc}
\text { Starch + Iodine } \underset{\text { endotherm }}{\rightleftharpoons} & \begin{array}{c}
\text { exotherm } \\
\text { colorless }
\end{array} \text { black-blue }
\end{array}
$$

Figure 1

The reaction between starch and iodine

From the reaction in Figure 1, it can be shown that if the temperature of the mixture between starch and iodine is lowered, the blackish-blue colour of the mixture becomes increasingly dark. Conversely, if the temperature of the mixture is raised, the colour of the mixture will be more colorless. The formation of a black-blue complex between starch and iodine in the form of $\mathrm{I}_{3}{ }^{-}$can be shown in Figure 2.

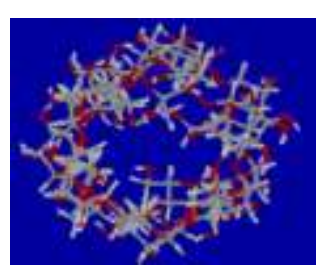

(a)

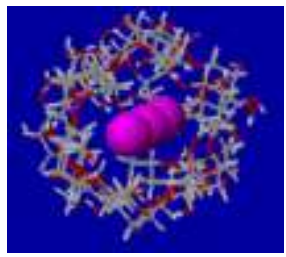

(b)

Figure 2

(a) Structure of coil or spiral of starch, (b) complex of starch-iodine (Figures are taken from Ophardt (2003), Starch-Iodine, Retrieved from http://chemistry.elmhurst. edu/vchembook/548starchiodine. html.)

In the green chemistry practicums, on the effect of concentration on the chemical equilibrium shift, the materials used were black tea solution, vinegar acid solution, and soapy water. The reactions that taking place at this chemical equilibrium shift are acidbase reactions which could be shown in Figure 3.

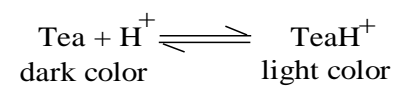

Figure 3

Acid-base equilibrium reaction of a black tea solution

Compounds in black tea playing an important role in the colour change in acidic and alkaline solutions are flavonoids, especially catechins and theaflavins (Brunning, 2015). 
The structure of catechin and theaflavin are shown in Figure $4 a$ and $4 b$, respectively. In alkaline solutions, groups of $\mathrm{OH}$ of catechins experience deprotonation (Cren-Olive et al., 2002) so that groups of $\mathrm{O}$ become negatively charged (Figure 5a). Otherwise, in acidic solutions, negatively charged $\mathrm{O}$ groups experience protonation (Kennedy et al., 1984) (Figure 5b). Protonation and deprotonation are forms of catechins structures that have a different colour because both structures absorb light at different wavelengths. The same applies to theaflavins.<smiles>Oc1cc(O)c2c(c1)O[C@H](c1ccc(O)c(O)c1)[C@H](O)C2</smiles>

(a)<smiles></smiles>

Figure 4

Structures of (a) catechin, and (b) theaflavin (Figures are taken from Brunning (2015), The chemistry of tea, Retrieved from http://www.compoundchem.com/2014/02/01/ polyphenols-antioxidants-the-chemistry-of-tea.)<smiles>[O-]c1ccc([C@@H]2Oc3cc(O)cc([O-])c3C[C@H]2O)cc1O</smiles>

(a)<smiles>Oc1cc(O)c2c(c1)O[C@H](c1ccc(O)c(O)c1)[C@H](O)C2</smiles>

(b)

Figure 5

Forms of (a) deprotonation and (b) protonation of catechins

Procedures and reactions of the green chemistry practicums are not yet available in chemistry textbooks but are found in journal articles. This drives students' curiosity to collect information from several sources to do the procedures and explain the reactions that occur in the green chemistry practicums. The effort of collecting information is one of the characteristics of students' active learning. Students are also actively involved in 
asking questions and give responses in the teaching and learning processes. This is accordance to the competency-based curriculum where students are expected to be actively involved in collecting information from several resources. On the contrary, procedures of the traditional chemistry practicums and their reactions have been widely found in chemistry textbooks.

Increasing curiosity fosters students' learning motivation. The growth of students' learning motivation is an important aspect in understanding subject matters, especially chemistry. The learning motivation will drive students to allocate more time to learn about topics of subject matters, take responsibilities for tasks, and search for information sources related to the subject matters being taught. Previous assumptions of students are that chemistry is identical to hazardous chemicals. However, after they work with the green chemistry practicums, they argue that chemistry is not as dangerous as imagined. Associated with learning motivation, Karpudewan et al. (2015) reported that students' learning motivation increases were a result of applying the green chemistry curriculum. Bakkara, et al. (2019) stated that the green chemistry practicums provided students with motivation and opportunities to overcome, explore, and enjoy science from the beginning. Still according to Bakkara et al. (2019), in the green chemistry practicums, students got the experience of examining each stage of practicums carried out, the chemical reactions, and the properties of materials used in practicums. Students not only followed existing practicum procedures but also developed the critical thinking skills in solving environmental problems. The green chemistry practicums were a chemistry learning approach developed by linking chemistry with real objects or phenomena around students' environment. They also provided environmental sustainability to prevent pollution. Besides, the green chemistry practicums also allowed students to learn both dangerous and environmentally friendly materials and made chemistry lessons more interesting, enjoyable, and meaningful. On the other hand, Sing \& Ravichandran (2014) stated that green chemistry was a pillar for sustainable development.

The results of this study are in accordance with previous research (Beyond Benign, 2011; Karpudewan et al., 2015). According to Karpudewan et al. (2015), students' learning outcomes attained through the green chemistry curriculum were better than the students' learning outcomes that are taught the regular curriculum. Meanwhile, Beyond Benign (2011) reported that the implementation of the green chemistry practicum could improve students' involvement in teaching and learning processes and students' understanding towards the subject matters. Therefore, students will study the subject matters more easily. Meanwhile, Braun et al. (2006) stated that green chemistry had the potential to considerably enhance chemistry learning and improves students' understanding of concepts.

Some researchers had developed the procedures of green chemistry practicum. Chandrasekaran et al. (2009) produced the green chemistry reactions, including (1) synthesis of acetanilide from aniline and acetic acid using a catalyst of zinc, (2) the bromination of trans-stilbene with hydrogen bromide and hydrogen peroxide in ethanol, (3) reaction of Diels-Alder from maleic acid and furan in water, (4) synthesis of adipic 
acid from cyclohexene, hydrogen peroxide, sodium tungstate, $\mathrm{KHSO}_{4}$, and aliquat 336, and (5) synthesis of biodiesel from vegetable oil and sodium hydroxide. Beyond Benign (2014) developed the green chemistry practicum procedures for acids, bases, and $\mathrm{pH}$ topics using materials of soda, lemon juice, lawn fertiliser, hibiscus tea, vinegar, orange juice, shampoo, baking soda, spaghetti sauce, milk, salt water, litmus paper, red cabbage, blueberries, and beets; and for the thermochemistry topic using materials of hydrogen peroxide, beef liver, and citric acid. Wright and Reedy (2002) developed the green chemistry practicum procedures for topics of the effect of concentration of reactant and temperature of the reaction rate. Materials used were vitamin $\mathrm{C}$ tablets, iodine tincture, starch, and hydrogen peroxide. Kimbrough et al. (1997) developed the green chemistry practicum procedures for the topic of the effect of the catalyst on the reaction rate. Materials used were hydrogen peroxide solution and beef liver.

The importance of integrating green chemistry into the educational curriculum had been demonstrated by some researchers. Kerr (2007) stated that this integration could prepare the green chemistry experts in designing chemical processes that were friendly to the environment. Braun et al. (2006) stated that the green chemistry practicums were not intended to replace the existing contents of the subject matter, but the classes should be taught the new methods. Meanwhile, Chandrasekaran et al., (2009) reported that the green chemistry practicums were not intended to replace the traditional methods drastically, but it should be considered to complement existing procedures.

There are four advantages being obtained from the integration of green chemistry into an educational institution, one of them is higher involvement and retention (Beyond Benign, 2011). Through the application of green chemistry at school, students will involve more in the teaching and learning. This produces a higher retention rate. The integration of green chemistry into the chemistry curriculum will motivate and give opportunities to students to solve problems, explore ideas, and enjoy chemistry early. Meanwhile, the curriculum of green chemistry leads to better understanding of students than that of regular chemistry (Karpudewan et al., 2015). Advantages of integrating the green chemistry practicums into education are (1) the chemistry laboratory becomes friendlier, safer, and cheaper; (2) students can repeat and modify laboratory procedures so that they can gain success in their work, (3) the green chemistry practicums can improve the students' learning motivation, and (4) the green chemistry can improve the students' learning outcomes.

Wastes produced from the green chemistry practicums are friendly to the environment (Kimbrough et al., 1997; Hjeresen et al., 2000; Can \& Dickneider, 2004; Clark, 2005; Braun et al., 2006; Chandrasekaran et al., 2009; Rani et al., 2012). These wastes can be naturally degraded by microorganisms. The degraded products are not dangerous to the environment and they can be turned into organic fertilizers. Therefore, the environment will be sustainable (Ranke et al., 2006; Kerr, 2007; Karpudewan et al., 2011; Sing \& Ravichandran, 2014; Singh et al., 2014). The sustainable development is very important as the next generation can still meet their needs as a result of the present generations' actions. Meanwhile, according to Karpudewan et al. (2011), the sustainable development guarantees an improved quality of life for all people, covering the present 
and next generations. The programs for the green chemistry practicums should guide sustainability in design and use materials processed economically, using energy resources rationally, and decreasing hazardous solids, liquids, and gases. The green chemistry practicums are not a new branch of science but rather a new philosophy of an educational approach through the application and extension of the green chemistry principles to contribute to the sustainable development. The green chemistry is a pillar for sustainable development (Ranke et al., 2006; Singh \& Ravichandran, 2014).

This research is still limited to the green chemistry practicum for the effect of temperature and concentration on the chemical equilibrium shift. Meanwhile, the green chemistry practicum for the effect of pressure and volume on the chemical equilibrium shift cannot be done because environmentally friendly chemicals have not been found as substitutes for hazardous chemicals. The way to overcome this is by conducting the practicums on a micro or semi-micro scale. Thus, the wastes produced are very little. The chemistry practicum carried out on the micro or semi-micro scales are also included in the green chemistry practicums because the definition of green chemistry is to replace or reduce the disposal of hazardous chemicals into the environment.

\section{CONCLUSION}

Based on the results of this study, it can be concluded as follows. There is a significant difference between students' learning outcomes taught by the green chemistry practicum methods and students' learning outcomes taught by the traditional chemistry practicum methods. The green chemistry practicum methods show better students' learning outcomes than the traditional chemistry practicum methods. In addition, these green chemistry practicum methods use materials that are safe for humans and friendly for the environment. In other words, the wastes generated from the green chemistry practicums can be decomposed by microorganisms in the environment.

Based on the results achieved in this study, it can be suggested that chemistry teachers should apply the green chemistry practicum methods in teaching the chemistry concepts. Besides the low cost, the green chemistry practicum methods can also improve the students' learning outcomes and can reduce and even prevent the release of hazardous chemicals into the environment.

This research implies that schools and chemistry teachers must provide environmentally friendly materials in schools to be able to carry out the green chemistry practicums. These materials can be obtained easily and are sold freely in drug stores. Thus, the operational costs of chemistry practicum are very cheap. The most important thing is that the materials used in chemistry practicum are safe for living things, especially humans, and the waste resulted does not pollute the environment (Bakkara et al., 2019) so that the concepts of sustainable development can be achieved (Sing \& Ravichandran, 2014). 


\section{REFERENCES}

Bakkara, C., Rahmawati, Y., \& Budi, S. (2019). Integration of green chemistry approach in essential oil extraction practice to develop students' critical thinking skills. In Rahmawati \& Taylor (Eds). Empowering Science and mathematics for Global Competitiveness (pp. 328-333). London: Taylor \& Francis Group.

Beyond Benign. (2011). Unleashing green chemistry and engineering in service of a sustainable future. New York, NY: Environmental Protection Agency.

Beyond Benign. (2014). Green chemistry replacements exercises. Retrieved March 21, 2017 from http://webcache.googleusercontent.com.

Braun, B., Charney, R., Clarens, A., Farrugia, J., Kitchens, C., Lisowski, C., Naistat, D., \& O'Neil, A. (2006). Completing our education green chemistry in the curriculum. Journal of Chemical Education, 83(8), 1126-1129. Doi: 10.1021/ed083p1126.

Brunning, A. (2015). The chemistry of tea. Retrieved March 21, 2017 from http://www. compoundchem.com/2014/02/01/polyphenols-antioxidants-the-chemistry-of-tea.

Bruno, A. \& Dell'Aversana, G. (2018). Reflective practicum in higher education: The influence of the learning environment on the quality of learning. Assessment \& Evaluation in Higher Education, 43(3), 345-358. Doi: 10.1080/02602938.2017.1344823.

Can, M. C. \& Dickneider, T. A. (2004). Infusing the chemistry curriculum with green chemistry using real-world examples, web modules, and atom economy in organic chemistry courses. Journal of Chemical Education, 81(7), 977-980. Doi: 10.1021/ed081p977.

Chandrasekaran, S., Ranu, B. C., Yadav, G. D., \& Bhanumati, S. (2009). Monographs on green chemistry experiments, Task Force, DST. Retrieved March 21, 2017 from http://www.dst.gov.in/green-chem.pdf.

Clark, J. (2005). Green chemistry and environmentally friendly technologies. In Afonso, C. A. M. \& J. G. Crespo (Eds). Green separation processes (pp. 3-18). Weinheim: Wiley-VCH Verlag GmbH \& Co.

Cren-Olive, C., Wieruszeski, J. M., Maes, E., \& Rolando, C. (2002). Catechin and epicatechin deprotonation followed by 13C NMR. Tetrahedron Letters, 43(25), 45454549. Doi: 10.1016/S0040-4039(02)00745-1.

Hikmah, N., Yamtinah, S., Ashadi, \& Indriyanti, N. Y. (2018). Chemistry teachers' understanding of science process skills in relation of science process skills assessment in chemistry learning. IOP Conf. Series: Journal of Physics. 1022. 012038. 1-7. Doi: 10.1088/1742-6596/1022/1/012038. 
Hjeresen, D. L., Schutt, D. L., \& Boese, J. M. (2000). Green chemistry and education. Journal of Chemical Education, 12, 1543-1547. Doi: 10.1021/ed077p1543.

Karpudewan, M., Ismail, Z., \& Mohamed, N. (2011). Green chemistry: Educating prospective science teachers in education for sustainable development at school of educational studies, USM. Journal of Social Sciences, 7(1), 42-50. Doi: 10.3844/jssp.2011.42.50.

Karpudewan, M., Roth, W. M., \& Ismail, Z. (2015). The effects of 'green chemistry' on secondary school students' understanding and motivation. The Asia-Pacific Education Researcher, 24, 35-43. Doi: 10.1007/s40299-013-0156-z.

Kennedy, J. A., Munro, M. H. G., Powell, H. K. J., Porter, L. J., \& Foo, L. Y. (1984). The protonation reactions of catechin, epicatechin, and related compounds. Australian Journal of Chemistry, 37(4), 885-892. Doi: 10.1071/CH9840885.

Kerr, M. E. (2007). Green chemistry and sustainable development. Maejo Journal of Science and Technology, 1(2), 95-97. Retrieved March 21, 2017 from http://www.mijst.mju.ac.th.

Kimbrough, D. R., Magoun, M. A., \& Langfur, M. (1997). A Laboratory experiment investigating different aspects of catalase activity in an inquiry-based approach. Journal of Chemical Education, 74(2), 210-212. Doi: 10.1021/ed074p210.

Listyarini, R. V. (2019). Promoting sustainability in undergraduate program: Students' perception in green chemistry course. International Journal of Indonesian Education and Teaching, 3(1), 67-79. Doi: 10.24071/ijiet.2019.030107.

Makarem, S., Dumit, N., Adra, M., \& Kassak, K. (2001). Teaching effectiveness and learning outcomes of baccalaureate nursing students in a critical care practicum: A Lebanese experience. Nursing outlook, 49, 43-49. Doi: 10.1067/mno.2001.111186.

Ophardt, C. E. (2003). Starch-iodine. Retrieved March 21, 2017 from http://chemistry. elmhurst.edu/vchembook/548starchiodine.html.

Pallant, J. (2001). SPSS survival manual: A Step by step guide to data analysis using SPSS for windows. Victoria: McPherson's Printing Group.

Putra, I. S., Susilaningsih, E., \& Wardani, S. (2018). Development of inquiry-based chemistry laboratory sheet oriented to green chemistry for improving the science process skills. Journal of Innovative Science Education, 7(1), 87-94. Retrieved March 15, 2019 from http://journal.unnes.ac.id/sju/index.php/jise.

Rani, B., Maheshwari, R., Chauhan, A. K., \& Singh, U. (2012). Potentiality of green chemistry for future perspectives. International Journal of Pharmaceutical and Chemical Sciences, 1/1, 97-104. Retrieved March 21, 2017 from http://www. https://www.semanticscholar.org/paper/Potentiality-of-Green-Chemistry-for-FutureRani-Maheshwari/eb9081541d8fd465ac561c94d86371fe75600c20. 
Ranke, J., Lenoir, D., Bahadir, M., \& Konig, B. (2006). A Green chemistry lab course. Pakistan Journal of Analytical and Environmental Chemistry, 7(2), 77-82. Retrieved March 21, 2017 from http://www.ceacsu.edu.pk/PDF\%20file/Journal\%20Vol\%207\% 20issue\%202/02-PJAEC-270307-14.pdf.

Redhana, I W., Sudria, I. B. N., Hidayat, I., \& Merta, L. M. (2017). Identification of chemistry learning problems viewed from conceptual change model. Jurnal Pendidikan IPA Indonesia, 6(2), 356-364. Doi: 10.15294/jpii.v6i1.9594.

Rocke, A. J. \& Usselman, M.C. (2020). Chemistry. Encyclopaedia Britannica. Retrieved March 10, 2020 from https://www.britannica.com/science/chemistry.

Ryan, G., Toohey, S. \& Hughes, C. (1996). The purpose, value, and structure of the practicum in higher education: A literature review. High Education, 31, 355-377. Doi: 10.1007/BF00128437.

Singh, A., Singh, S., \& Singh, N. (2014). Green chemistry: Sustainability an innovative approach. Green chemistry and sustainability, 2(2), 77-82. Retrieved March 21, 2017 from https://www.researchgate.net/publication/269405653_Green_Chemistry_Sustain ablity_An_Innovative_Approach_Green_Chemistry_and_Sustainability.

Singh, L. \& Ravichandran, S. (2014). Green chemistry: The future pillars. International Journal of ChemTech Research, 6/1, 147-149. Retrieved March 21, 2017 from http://sphinxsai.com/2014/ChemTech/JM14CT1_50/CT=18(147-149)JM14.pdf.

Suardana, I N., Redhana, I W., Sudiatmika, A. A. I. A. R., \& Selamat, I N. (2018). Senior high school students' critical thinking skills in local culture-based 7E learning cycle model. International Journal of Instruction, 11(2), 399-412. Doi: 10.12973/iji.2018.11227a.

Sudria, I. B. N., Redhana, I W., Kirna, I M., \& Aini, D. (2018). Effect of Kolb's Learning Styles under Inductive Guided-Inquiry Learning on Learning Outcomes. International Journal of Instruction, 11(1), 89-102. Doi: 10.12973/iji.2018.1117a.

Taha, H., Suppiah, V., Khoo, Y. Y., Yahaya, A., Lee, T. T., \& Damanhuri, M. I. (2019). Impact of student-initiated green chemistry experiments on their knowledge, awareness and practices of environmental sustainability. IOP Conf. Series: Journal of Physics, 1156. 012022. Doi: 10.1088/1742-6596/1156/1/012022.

Tesfamariam, G., Lykknes, A., \& Kvittingen, L. (2014). Small-scale chemistry for a hands-on approach to chemistry practical work in secondary schools: Experiences from Ethiopia. African Journal of Chemical Education, 4/3, 48-94. Retrieved March 21, 2017 from https://www.ajol.info/index.php/ajce/article/download/104097/94208.

Ural, E. (2016). The Effect of guided-inquiry laboratory experiments on science education students' chemistry laboratory attitudes, anxiety and achievement. Journal of Education and Training Studies, 4(4), 217-227. Doi: 10.11114/jets.v4i4.1395. 
Wright, S. W. \& Reedy, P. (2002). The vitamin C clock reaction. Journal of Chemical Education, 79(1), 41-43. Doi: 10.1021/ed079p41. 